FTAMP 03.29.00

\title{
Нұрдәулетова Б.И.
}

филология ғылымдарының докторы, профессор, Ш. Есенов атындағы Каспий мемлекеттік технологиялар және инжиниринг университеті,

Қазақстан, Ақтау қ., e-mail: nurdauletova@mail.ru

\section{МАНҒЫСТАУ ЖӘНЕ МАНҒЫТТАР}

\begin{abstract}
Маңғыстау тарихында оғыздар мен қыпшақтардан кейінгі тарихи маңызы бар кезең - А^тын Орда, Ноғайлы дәуірі.16 ғасырдың екінші жартысында Ноғай Ордасы ішкі-сыртқы жағдайларға байланысты 2-3 бөлікке ыдырағаны белгілі, олар: Үлкен Ноғай ұлысы, Кіші ноғай ұлысы және Алты ауы^ ұлысы, Жембойлық ұлысы. Кіші Ноғай ұлысы негізін қалаған Жем мен Жайықтың арасын, Маңғыстау мен Үстіртті мекендеген, жыр-дастандарда "он сан ноғай» деген атқа ие болған жұрт екені айтылады. Маңғыстау мен Үстірттің топоареалында Ноғай, Ноғайты, Ноғайлы, Орақ, Мамай, Қарасай, Қазы, Сары, Қалау, Қараүлек, Қарашаш, Манашы, Күйкен, ӘАіл т.б. атаулар кездеседі. Ноғайлы батырлары туралы «Қырымның қырық батыры» жырлар циклінің де поэтикалық ареалы Маңғыстау аймағы болуы тегін емес. Ноғайлының бас биі ЕАіге маңғыт тайпасынан шыққандықтан, оның билеген елі «маңғыт жұрты» аталғаны тарихи деректерде көрсетілген. Біздің мақаламызда маңғыттардың Маңғыстауды мекендегені, олардың бір кездерде бір Орданың қанатының астында болған кіші жүз, соның ішінде адайлармен этнографиялық сабақтастығы туралы сөз болады. Маңғыстау топонимі мен маңғыт этнонимінің негізі туралы болжамдар ұсынылады.
\end{abstract}

Түйін сөздер: Маңғыстау, маңғыттар, ЕАіге, Нұр-Ата, А^ғи-Нұр, этнографиялық, салт-дәстүр, ырым, қабіртастар, ғимараттар.

Nurdauletova B.I.

doctor of Philology, Professor, Sh. Esenov Caspian state University of technologies and engineering, Kazakhstan, Aktau, e-mail: nurdauletova@mail.ru

\section{Mangistau and Mangiti}

The next important historical period in the history of Mangistau after the Oghuz and Kipchaks is the Golden Horde, the period of Nohili. In the second half of the 16th century, the Nogai Horde in relation to internal and external circumstances are divided into 2-3 pieces, among which were: the Great Nogai Ulus, the Youngest of the Nogai ulus Ulus and six villages, Gembicki Ulus. The founder of the Younger Nogai Ulus was a people who lived between the rivers Zhem and Zhaiyk, between Mangistau and Ustyurt, and in the poems was nicknamed «he San Nogai» («ten Nogais»). In Toporeals Mangistau and Ustyurt there are such names as Nogai, Nogayty, Nogaili, Orak, Mamai, Karasai, Kazi, Sarah, Kalau, Karaulek, Karashash, Manasi, Kuiken, Adil etc. No accident in Mangystau region is the habitat of the poetic cycle of poems "Yranny Kyryk batyrs» («Forty batyrs of the Crimea»). In the historical sources say that since the main bi (judge) Nogai Edige was a native of the tribe of Mangit, the people that he led, also became known as "Maritime». The article describes how the mangits lived in Mangystau, as well as their ethnographic cooperation with the representatives of the Younger Zhuz, namely with the adais, with whom they were under the wing of one Horde. Assumptions about the basis of the toponym Mangistau and the ethnonym Mangit are provided.

Key words: Mangistau, mangiti, Edige, Nur-ATA, Algi-Nur, Ethnography, traditions, beliefs, gravestones, buildings. 


\author{
Нурдаулетова Б.И. \\ Аоктор филологических наук, профессор, Каспийский государственный университет \\ технологий и инжиниринга имени Ш. Есенова, \\ Казахстан, г. Актау, e-mail: nurdauletova@mail.ru
}

\title{
Мангистау и мангиты
}

\begin{abstract}
Следующим важным историческим периодом в истории Мангистау после огузов и кипчаков является Золотая Орда, период Ногайлы. Во второй половине 16 века Ногайская Орда в связи с внутренними и внешними обстоятельствами разделилась на 2-3 части, среди которых были: Большой Ногайский Улус, Младший Ногайский Улус и Улус шести аулов, Жембойский Улус. Основателем Младшего Ногайского Улуса был народ, который обитал между реками Жем и Жайык, между Мангистау и Устюртом, а в поэмах был прозван «он сан ногай» («есять ногайцев»). В топоареалах Мангистау и Устюрта встречаются такие названия, как Ногай, Ногайты, Ногайлы, Орак, Мамай, Карасай, Казы, Сары, Калау, Караулек, Карашаш, Манашы, Куйкен, Адиль и др. Не случайно Мангистауский регион является поэтическим ареалом цикла поэм «Қырымның қырық батыры» («Сорок батыров Крыма»). В исторических источниках говорится, что поскольку главный би (судья) ногайцев ЕАиге был родом из племени мангит, народ, который он возглавлял, тоже стал называться «мангитами». В статье говорится о том, как мангиты обита^и в Мангистау, а также об их этнографическом содружестве с представителями Младшего жуза, а именно с адайцами, с которыми они были под крылом одной Орды. Предоставляются преАположения об основе топонима Мангистау и этнонима мангит.
\end{abstract}

Ключевые слова: Мангистау, мангиты, ЕАиге, Нур-Ата, Алги-Нур, этнографический, традиции, поверья, надгробные камни, зАания.

\section{Kipicпе}

Үстіміздегі жылдың мамыр-қараша айларында Маңғыстау аймағының тарихи-мәдени мұраларын кешенді зерттеуге арналған экспедиция ұйымдастырылған болатын. Экспедиция жұмысының бір бағыты Маңғыстаудың ноғайлы кезеңіне арналды. Ноғайлы дәуірінің тарихи-архитектуралық ескерткіші ретінде Маңғыстау ауданының Онды аулынан оңтүстік шығысқа қарай 19,5 км қашықтықта орналасқан Қарауылкүмбет қойылымындағы кесенеге археологиялық қазба жұмысы жүргізілді. Аталған кесененің қас бетінде «Шаһидолла Едіге», ал оң жақ бетіндегі сыртқы қабырғаның төменгі плитасында «Едіге бұ баһадұр болдұ, би болдұ», «Әбубашар...» деген жазулар бар. Кесене уақыттың, табиғаттың небір қысталаңына төтеп берген, бір кездерде жергілікті плита тастармен қапталып, зәулім етіп салынған салтанатты ғимарат қазір жартылай қирап, ішкі жағы құланды тастармен көмілген. Қазба барысында кесененің ортасында және сәл шеткерілеу екі қабіртас табылды. Қабіртастардың астынан бірі ер адамның, екіншісі әйел адамның сүйегі қазып алынды. Қазба жұмысын жүргізген археологтардың және басқа да зерттеушілердің пайымдауынша, қабір басындағы тастардың қойылу уақыты мен ғимараттың салыну кезеңі бір емес, яғни ғимарат кейін салынған. Мәйіттердің жанында қосымша жерленген зат- бұйымдары жоқ. Ер адамның мәйіті барынша жақсы сақталған, басын құбылаға беріп, жастық тас төсеген, мойнын сәл оң жағына бұрып, маңдайын Темірқазық жұлдызына бағыттаған. Оң қолын ұзына бойына жіберіп, сол қолын кіндік тұсына қойған. Лақат-көр онша терең емес, тіке қазылған, бетіне жүзген ағашынан белағаштар салған. Көрдің бетін таспен емес, ағашпен жапқанына қарағанда, мәйіт асығыс және құпия жерленген, кесене кейіннен салынған. Жанындағы әйел адамның қабірі жартылай кесене іргетасының астында қалған, соған қарағанда ер адамға салынған кесене - іргесіндегі қабірді де қоса қамтып кеткен болуы керек. Қазіргі таңда табылған сүйектер антропологиялық, радиоуглероводтық сараптауға жіберілді (Маңғыстау экспедициясы, 2018: 110). Қазақтың тарихында батырлығымен, билігімен даңқы шыққан 4 Едіге болған (Құнтөлеуұлы, 2013). Соның ішінде өзінің тарихи да, эпикалық та биографиясы жағынан Маңғыстауға жақын тұрған Ноғайлының биі әрі батыры Едіге.

«Қырымның қырық батыры» жырлар циклінің бас қаһарманы - Едіге батырдың прототипі, тарихи тұлға, Алтын Орданың беклер бегі Ноғай Ордасының негізін қалаған Едігенің шыққан тегі туралы зерттеулерде - маңғыт (ақ маңғыт) (Бартольд, 1927; В.М. Жирмунский, 1974; В.В. Трепавлов, т.б.), ибн Арабшахтың жазбаларында - қоңырат (История Казахстана.., 2005: 332), Қ. Жалайыри шежіресінде - қыпшақтың 
күшігер тайпасынан шыққан (Қадырғали Жалайыри, 1997: 114-115) деп көрсетеді, ал Деннеби тіпті өзбек (Әнес Сарай, 2009: 54) тайпасынан шыққан дейді. Әбілғазы Баһадүрдің «Түрік шежіресінде» (Әбілғазы, 1999: 108) Едігенің өздерін маңғыт атаған қауымның билеушісі екендігі, бірақ шыққан тегінің дүдәмалдығы айтылады.

\section{Маңғыттар}

14 ғасырдың соңында саяси аренаға шығып, Алтын Ордадан бөлініп, жаңа Орда құрған, екі жүз мыңнан астам тұрақты әскері бар Едігенің куатты мемлекеті «Маңғыт жұрты» деп аталғаны белгілі. Маңғыттар туралы Рашид адДиннің «Жамиғ ат-тауарих» атты еңбегінде (Рашид ад-дин, 1999) және «Моңғолдардың құпия шежіресіндегі» деректерде келтіріледі. Басқа да тайпалармен бірге моңғол халқының негізгі бөлігін құраған маңғыттар кейін Дешті-Қыпшақ жерінде Жошы ұлысының батыс бөлігін иемденген деген пікірлер айтылады. В.В. Трепавлов маңғыттар Шыңғыс империясының «сол қанатында» болды десе (Трепавлов В.В., 2002: 52), Әнес Сарай Рашид ад-диннің еңбегіне сүйеніп, маңғыттардың Шыңғыс хан заманындағы мынбасы Құйылдыр шешеннің ұрпақтары Мөңке-Қалжа, Мулукур-Қалжаның Иранға келіп Хулагу қағанның қызметінде болғандығын, олай болса, маңғыттардың XIII ғасырдың орта шенінде батысқа (ДештіҚыпшақ жеріне) қоныс аударуы басы ашық мәселе екендігін айтады (Сарай Ә., 2009: 13). Ал маңғыттардың Алтын Орда тұсында хан тағының төңірегіне тартылуын Орыс ханның билігімен байланыстырады: «1358 жылы Орысоғлан Жыр-Құтуды өлтіріп қырғызға қашқанда Ноғай, Шығай ордасында жан бақты. Ақордаға хан болғанда оларды ілестіре келді. Олардың арасында маңғыттар да бар еді...» (Сарай, 2009: 14), - дейді. Зерттеуші Алтын Орда аймағында маңғыттардың екі қонысы болған деп көрсетеді: бірі - Созақтағы Құмкентте, екіншісі ЕділЖайық арасы. Екі мекеннің да Едігеге қатысы бар: бірі - оның туып, ержеткен, бабалары жерленген атамекені болса, екіншісі - Орыс ханнан қашып, маңғыт ағайындарын сағалап келіп, паналаған, кейін билік құрған ордасы.

Зерттеу еңбектерден: «XIV ғ. соңына қарай Жайық пен Еділдің арасындағы тайпаларды біріктірген қауым өзін маңғыттар, ал өз ұлысын «Маңғыт жұрты» атады. «Ноғайлар», «ноғайлықтар», «Ноғай Ордасы» деген атау- лар деректерде XVI ғ. бас кезінде пайда болады» (XIII-XY ғ. Ноғай ордасы...), - деген пікірлерді кездестіреміз. Әнес Сарай Ноғай атауын Алтын Орданың әскербасы Ноғай есімімен байланыстырған пікірлерді дұрыс деп есептейді. Түрлі тарихи-жазба деректерге сүйеніп: «Белгісіз Ноғайдың биік баспалдақтарға өрмелеп шығуы Берке хан тұсында болды (1257-1266 жж.). Демек Ноғай Алтын Орда қолбасы дәрежесіне дейін көтеріліп, Днепр-Дунай тарапынан жаңа иеліктер алғанға шейін ортаңғы және жоғарғы Еділ-Жайықты қоныс еткен.

Ноғайдың өлімінен кейін бұл өңір маңғыттарға берілгенмен, Ноғай жұрты аты қалмаған, өшпес-өлмес ел жады ақыры маңғыт атауын ысырып шығарған» (Сарай, 2009: 15), - дейді. Сөйтіп, өздерін «маңғыт жұрты» деп атаған Едігенің елін өзгелер «ноғайлылар» деп атап, жазба деректерге Ноғай Ордасы атауымен еніп, тарихта солай айту қалыптасқан болуы керек. И.Х. Калмыков, P.X. Керейтов, А.И. Сикалиевтердің бірлескен еңбегінде Ноғай ұлысының орнына XIV ғасырда Едіге тұсында Еділ мен Жайық аралығында құрылған жаңа этникалық топ ноғай атауын қайта жаңғыртты деп көрсетіледі [Калмыков, 1988]. Ал маңғыт тайпасы осы бірлестікті құраған көп тайпалардың бірі ретінде аталады. Р.Керейтовтің ноғайлылардың этногенезіне арналған еңбегінде ноғайлыны құраған басты тайпалардың қатарында бірінші маңғыт аталады (Керейтов, 1999: 21). Едіге туралы жырлардың бұлғар татарлары арасында тараған нұсқасында ғана Едігенің тегі маңғыт екені Тоқтамыстың сөзінде айтылады. Қарақалпақ нұсқасында Едігенің тегі қоңырат деп сипатталады. Қазақ нұсқаларында Едігенің тегі Баба Түкті Шашты Әзиз әулиемен байланыстырылады. Бұл - Едігедей ұлы бидің тегін қасиетті тұқымнан шығарып көрсету мақсатындағы халық қиялының жемісі болса керек.

\section{Маңғыттар мен Маңғыстаулықтар}

Біз Едігедей ұлы бидің ұлысы болған маңғыт жұртының қазіргі ұрпақтарын іздеп жолға шықтық.

Біздің экспедиция Өзбекстанның Бұқара, Навои өңірлерін аралап, маңғыт рулары жиі қоныстанған Кенимех ауданы, Шоркөл ауылына тоқталды. Қарақалпақ халқының құрамындағы алты арыстың үлкен бөлігі Маңғыттар 30 рудан тұрады. Соның ішінде Темірқожа маңғыттан тарайтын Шәкір Арипов ақсақал бізге Маңғыттардың шежіре-тарихын әңгімелеп берді. 
Ноғай Ордасы ыдырап, оның құрамындағы тайпалар жан-жаққа бытырағанда, маңғыттар Бұхара жаққа барып, өздерінің хандықтарын құрған. Бұқар хандығының бірнеше әмірі маңғыт тайпасынан болды. Бұқараның соңғы әмірі маңғыт тайпасынан шыққан Сейіт Әлімхан 1920 жылы Қызыл Армия басып алғаннан кейін, Ауғанстанға барып паналайды.

Руы ақмаңғыт Әбдірахманов Мамырайым ағамыздың үйіне барғанымызда, оның жаздық баспанасын көріп таң қалдық. Баспананың архитектурасы ерте кезеңдегі дыңдарzа қатты ұқсайды. Ғалымдар ерте дәуірдегі архитектуралық құрылыстың алғашқы нұсқасы дыңныңң үлгісі ретінде Қозы Көрпеш Баян сұлу мазарын атайды (Әлкей Марғұлан, 1985). Осындай мазарлар Маңғыстауда да бар. Дыңңның ерекшелігі табиғи тастардан балшықпен қиюластырып, конус формасында биік етіп салынады. Есігі жерден әлдеқайда жоғарыда тұрады. Мамырайым ағамыздың жаздық баспанасы да дәл сондай формада, кірер есігі биікте, баспалдақпен өрмелеп шықтық. Іші киіз үй сияқты шеңбер формасында. Бұндай үйлер қарақалпақтарда күлбе деп аталады екен. Осы сияқты ерекше формадағы тағы бір үйдің түрі құосай үй деп аталады.

Шәкір ақсақалдың түсіндіруінше, Кенимех атауы бастапқыда «конмах», «конмух» деген арабтың «отты жалын» мағынасындағы сөзінен шыққан. Маңғыттардың ғұрпы бойынша жаңа түскен келін жанып жатқан отты үш рет айналып, үстінен аттауы керек. Бұл - жаңа өмірге қадам басқан жас жанның бойын отпен тазарту, аластау ырымынан шыққан. Қазақтың келін түскенде бетін ашқаннан кейін, үйге кіргізіп, табалдырықтан аттатып, отқа май салып, жанып жатқан майдың жалынымен жас келінді аластау ырымы әлі күнге дейін Маңғыстауда қолданылады. Маңғыстау этнографиясын зерттеу тақырыбымызға дерек беретін тағы бір этнографиялық деталь - маңғыт келіндерінің сәлем ету салты. Келіндердің жасы үлкен қайын жұртына иіліп сәлем ету үрдісі, негізінен, Қазақстанның оңтүстік өңірлерінде және Маңғыстауда сақталған. Қызылорда, Түркістан облыстарында келіндер қолын кеудесіне қойып, басын сәл иіп сәлем салса, Маңғыстаудың келіндері оң жақ алақанын тізесіне қойып және тізесін бүгіп сәлем етеді. Міне, осы маңғыстаулық үрдістің дәл көшірмесін біз Шоркөлдегі келіндерден көріп, еріксіз таңғалдық. Кенимех аудан орталығындағы респонденттерімізден жинаған этнографиялық деректердің қатарында бізді қызықтырған өлімнің артын күтуге қатысты ырымдар болды. Мысалы, күйеуі қайтыс болған жесір әйел жыл өткенге дейін басына ақ орамал, үстіне көк көйлек киюге тиісті. Күйеуінің жылдық садақасы тарағаннан кейін төркіндері ақ көйлек тігіп әкеліп кигізіп, «көгің ағарды» деп тілек білдірген. Маңғыстау этнографиясы бойынша жинаған мәліметтерде көк орамал тартуды - жаман ырым санайтын түсінік бар.

Біз өзімізді «Қазақстаннан, Маңғыстауданбыз» деп таныстырғанымызда, бірнеше маңғыт руының адамдары: «Маңғыттаудан дейсіз бе?» деп сұрап қалды. Біз қалжыңы ма, шыны ма, болмаса, Маңғыттау деген жер бар ма? деген оймен тосылып қалдық. Кейіннен білгеніміз, шынымен де маңғыттар өздерінің арғы тарихын Маңғыстаумен байланыстырады екен...

Қарақалпақстанның «Айдын жол» газетіне шыққан журналист Б. Меңдібаевтың қарақалпақ халқының тарихын Маңғыстау жарты аралымен байланыстыратын мақаласында: «Қарақалпақ ғұламалары жазып қалдырған тарихи мұраларға қарағанда жайылқан ныспымен ат көтерген бесенелер (осы халықтың ескі атауы) һiжра есебімен 250-300 жылдардың өзінде-ақ осы жарты аралды мекен еткен екен. Тарихи жазбалар бесене (печенег) жұртының сол тұста Гурганж (Арал) теңізінен Атил (Еділ) өзеніне дейінгі алқапта ежелгі Бұлғар, Хазар қағанатымен қанаттас жасағанына анықтық енгізеді. Міне осы кезеңде оғыздармен одақтас болған қарақалпақ қауымының қазаяқлы, қостамғалы, бөгежелі, қанжығалы, айтамғалы, жыланлы, ырғақлы, уақтамғалы тайпалары Маңғыстау түбегін жайлағаны баяндалыпты... Бірнеше ғасыр бойы осы өлкені мекен тұтып, дай (адайлардың ежелгі атауы), кәспий (бұл ру Арал, Сағақты қарақалпақтарының арасында әлі бар) секілді қауымдармен қоян-қолтық араласып жасаған бесенелер, яғни қоңырат-қарақалпақтар біртіндеп батысқа қарай жылжи бастайды да, жартыаралда қалғандары жергілікті елдер құрамына енеді», - дей келіп: «Жайылқан о баста тек қоңырат елінің аты болса, кейін жалпы қарақалпаққа телініп айтылып кеткен. Өйткені Жайылқан ұрпақтары болмыш қоңыраттар қарақалпақтың негізін қалаған бас арыс саналады да, саны жағынан да осы халықтың жетпіс пайызын құрайды... Ноғайлы заманында бұл өңірге маңғыт елі орналасып, ірге кеңейткені тарихтан аян. Қарақалпақтың қабырғалы арысы саналған маңғыт елінен әйгілі Едіге би шыққан. Осы тұлға 1391 жылы Ноғай ордасын құрып, жаңа саяси одаққа негіз салған еді. Сол кезде адайлар да маңғыт бірлестігіне кірген-тін. Едіге 
би маңғыт болған соң, осы орда «Маңғыт үйі» деп те аталған. Тап сол тұстан бастап түбек атауы «Маңғытқыслау немесе Маңғытқашлақ» атала бастаған дейді тарих ғылымын тексергендер» (Меңдібаев Б., 2008), - деп жазады. Автор Маңғыстаудағы маңғыттардың тарихы туралы «тарихи жазба деректер бар» десе де, сол тарихи деректерден сілтеме көрсетпеген.

«Жеті жұрт келіп, жеті жұрт кеткен» Маңғыстауға сол келіп-кеткен жұрттың бірі оғыздар мен печенегтер екені Маңғыстау тарихына қатысты барлық зерттеу еңбектерде айтылады. Олардың тарихи іздері Маңғыстау топонимикасында сайрап жатыр. Сондай-ақ, Едігенің Ноғай Ордасының туын тіккен, кейінгі ұрпақтары билік құрып, жан-жаққа аттанған қара шаңырағы Қазақстанның батыс өлкесі, соның ішінде Маңғыстаудың қара ойы екені анық.

«Қырымның қырық батыры» жырлар тізбегінің осы өлкеде ғана толық жүйесімен сақталуы тегін болмаса керек. Маңғыстау топонимикасындавы Новай, Новайты, Новайль, Ногайтөбе, Орақ, Мамай, Қарасай, Қази, Сары, Қалау, Баба түкті, Шашты әзіз, Хантөрткүл, Манашы, Күйкен (Қондыбай, 2008) т.б. атаулар бұл жердің эпикалық әлеуетін толықтыра түседі.

\section{Қорытынды}

Біздің осы мақаланы жазуымызға себеп болған «Маңғыстау мен маңғыттардың байланысы» деген мәселе еді. Ең алдымен, Маңғыстаудың адайлары сияқты маңғыттар да өздерінің ата-бабалары Түркістан айналып келген деп түсінеді. Маңғыттардың «Жиделібайсыны» немесе ата-бабасына қоныс болған құтты мекені - Нұр ата деген жер. Адайлар үшін Қаратаудың бойындағы қос бұлақ - Қара-Байыр, Алғи-Нұр - иісі алаштың жайлаған жері, құтты қонысы. Қаратаудағы Нұр бұлақ туралы Адайдың атақты тақтағы - Қашаған жыраудың бірнеше толғауы бар. «Адай тегі» дастанында:

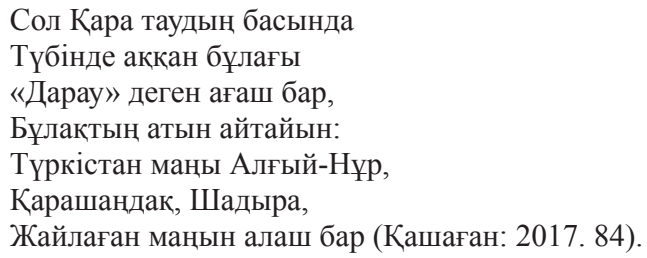

«Атамекен» дастанында:

Әзіреттің кең ойы,

Алғи судың өн бойы
Атамыз қонған жер екен.

Көршілес елдер жау болып,

Іздегендері дау болып -

Кетіпті біраз берекем.

Әзіреттің ойында,

Қара-Байыр, Алғи-Нұр

Деген судың бойында

Алшын деген аз ауыл

Қытайменен жау болып

Көшіпті салып қарауыл,

Аттың мініп жарауын.

Жыйнады ноқта-сіргені,

Көтеріп көшкен іргені,

Ел көше аузын бірледі...(Қашаған, 2017: 96-97)

Қытаймен қидаласып, Түркістаннан үдере көшкен адай елінің Маңғыстаудың ойына қалай құлағаны жыр тілімен:

Жыйылып ерлер құралы,

Билерім кеңес құрады.

Шайқылар жатқан қара жұрт,

Баяғы атамыздың тұрағы -

Маңғыстаудың қара ойын

Ернектен қарап тұрады.

Шақырғандай болады

Шашбаудайын сылдырап

Ана Қаратаудың бұлағы.

Бұдан ары шыдамай

Қараойға жұртым құлады, -

деп суреттеледі. Сөйтіп, Түркістанның Қаратауынан қозғалған адайлар өздерінің бұрынсоңды қалдырып кеткен, «шайқылар жатқан қара жұртына» - Маңғыстаудың Қаратауына келіп біржолата қоныс тебеді. Осы көрініс «Жұт жылы» дастанында:

Қарабайыр, Нұр суы,

Айналып Сауран келгелі...(Қашаған, 2017: 105)

деп еске алынады. Қарақалпақстанның белгілі фольклортанушысы Сейдін Әмірланның 2008 жылы жазып алған деректерінде Ізбасар Асылбекұлы деген ел ақсақалы мынадай дерек айтады: «Ол кезде Елібайды «Нұр» деп те атаған. Нұр өлкесін негізінен қарақалпақтың қоңырат арысы билеп тұрған. Нұрдан жоғарғы жағын маңғыттар жайлаған. Нұр өлкесінің орталығы Нұрата шәрі болған.

Қарақалпақтың белгілі бір кісісі қайтыс болса, Нұратадағы «Қарақалпақ қорымы» деп аталатын ескі мазаратқа апарып жерлеген. Осындағы шару жайы қарақалпақтардың малын сатып, базар-ошар ететін жері негізінен сол Нұрата базары болған. Сонан кейін: 
Қарақалпақтың базары да,

Қара мазары да Нұратада, -

деген сөз қалған. Қарақалпақтар Нұрата қаласын әрі қорғаған, әрі сол жерге билігін жүргізген. Қазақтар қарақалпақтарды Сырдың бойынан ығыстырса, қарақалпақтар Нұр атаға қарай қазақтарды өткізбеген, содан ел арасында:

Қазаққа Нұр жоқ,

Қарақалпаққа Сыр жоқ,

деген де сөз қалған. Нұратаның түпкілікті қарақалпақтары өздерін «жиырма төрm ата маңқылилау» дейді. Бұлар о баста Маңздытқыстау деген жерден келген қоңыраттар екен. Олар көп заман түрікпендермен қоныстас болған. Сол үшін кейін келген қарақалпақтар оларды «түрікпен» немесе «жаман түрікпен» деген лақаппен атап кеткен. Бұлар маңғыттар емес, маңқыıылау қ̧оңыыраттары. Біздер бала кезімізде мынадай шақшақ (әзіл тақпақ) айтушы ек:

Маңъқышлауда бір қъыз бар,

Манлайында жұлдыз бар,

Алайын десем пұльмм жоқ,

Берейін десем гүлім жоқ..., - деп... Бұлар да кейін тәжік-сартпен араласып кетті. Нұрдың Қаратауын ен жайлаған «жаман түрікпен» тұқымдары біздің өз ағайындарымыз» (Экспедиция, 2018), - дейді.

Сонда адайлар Сауран айналып, Түркістаннан Маңғыстауға келсе, маңғыттар Маңғыстаудан ығысып, Сыр бойына, одан Түркістанға барған болып шығады. Қашағанның дастанында айтылатын, Әзіреттің ойында, Қара-Байыр, АлғиНұр деген судың бойында алшындармен бірде тату, бірде араз болып жүрген қарақалпақтың бір тақтасы қытайлар емес пе екен деген ой туады (шежіре бойынша қарақалпақ - мүйтен, қ̧оңырат, қылтай, қылишақ, кенегес, маңзъыт деп алты атаға бөлінеді).

Осы уақытқа дейін Маңғыстау атауының этимологиясы түрлі ұғым-түсініктермен байланыстырылып келді. Ал оның маңғыт этнониміне қатыстылығы туралы мәселе арнайы зерттеуді қажет етеді. Ноғайлының беглер бегі Едігенің «Маңғыт жұртының» бір кездердегі дәуірлеген заманының куәсіндей болып Маңғыстаудың қара ойында жатқан ноғайлы қорымдары мен Қарауылкүмбет кесенесінің сыры ашылса, талай жұмбақтың шешуі табылатыны сөзсіз.

\section{Әдебиеттер}

Әбілғазы. Түрік шежіресі (2009). Алматы

Әнес Сарай (2009). Ноғайлы. Алматы: Арыс.

Әлкей Марғұлан. (1985). Ежелгі жыр аңыздар. Алматы: Жазушы.

Бартольд В. В., Отец Едигея, в сб.: Изв. Таврич. об-ва истории, археологии и этнографии, Т. 1, Симферополь, 1927.

Жирмунский В.М. (1974). Тюркский героический эпос. Ленинград: Наука, 1974.

История Казахстана в арабских источниках. (2005). 1-том, Алматы.

Калмыков И.Х., Керейтов Р.Х., Сикалиев А.И. (1988). Ногайцы: Историко-этнографический очерк. (1988). Черкесск: Ставроп. кн. изд-во, 1988. 230 с.

Керейтов Р.Х. (1999). Этническая история ногайцев (к проблеме этногенетических связей ногайцев). Ставрополь.

Қадырғали Жалайыр. (1997). Шежірелер жинағы, Алматы: Қазақстан.

Қашаған Күржіманұлы (2016). Тіл таңбалы ақындар. 5 томдық. Құрастырған Ж.Жылқышиев. 2-том. Ақтау.

Құнтөлеуұлы А. (2013). Едіге би және Ноғай Ордасы. Алматы: Дәуір.

Маңғыстау экспедициясының есебі (2018). Ақтау.

Мендібаев Б. (2008). Жарыаралды жайлаған Жайылқандар// «Айдын жол» газеті, 2008, сәуір

Рашид ад-дин. (1999). Сборник летописей. 2-книга. Москва.

Трепавлов В.В. (2002). Ногайская Орда. Москва.

XIII-XY ғғ. Ноғай Ордасы. Солтүстік Қазақстан және Батыс. //https://qazbrand.info/all/510/ XIII-XV centuries-Nogai-ordasy-North Kazakhstan region/ Қаралған күн: 7.10.2018.

\section{References}

Abilgazi. (1999). Turik shezhiresi [Turkic chronicle]. Almaty, 1999

Alkei Margulan. (1985). Ezhelgi zhyr anyzdar [Ancient fat legends]. Almaty: Zhazushy, 1985

Anes Sarai S. (2009). Nogaily. Almaty: Arys.

Bartold V.V. (1927). Otec Edigeja [ The father of Edigei]. Izv. Tavrich. about history, of

archaeology and Ethnography, vol. 1, Simferopol.

Zhirmunsky V. M. (1974). Tjurkskii geroicheskii epos [Turkic heroic epic]. Leningrad: Nauka. 
storija Kazahstana v arabskih istochnikah (2005). [History of Kazakhstan in Arab sources]. 1-volume, Almaty.

Kalmykov I.H., Kereitov R.H., Sikaliev A.I (1988). Nogajcy: Istoriko jetnograficheskij ocherk. [Nogais: Historical ethnographic sketch]. Zherkesk: Stavropol. kN. publishing house.

Kereitov R.H. (1999). Jetnicheskaya istorija nogajcev (k probleme jetnogeneticheskih svjazej nogajcev). [Ethnic history of Nogays (to the problem of ethno-genetic relations of the Nogays)]. Stavropol.

Hadyrgali Zhalairi. (1997). [Shezhireler zhinaғy]. Collection of Chronicles, Almaty: Kazakhstan.

Khashagan Kurzhimanuly (2016). Til tanbaly akyndar. [Language poets-digit]. In 5 volumes. The year of Compiling the dictionary is implemented two-way transfer. Volume 2 . In the dictionary implemented two-way transfer.

Khuntoleuuly A. (2013). Edige bi zhane Nogai Ordasy [Edyge Biya and Nogai Horde]. Almaty: Dauir.

Mangystau enspedicijasynyn esebi (2018). Aktau [Report of the expedition of Mangistau]

Mendybaev B. (2008). Zharyaraldy zhajlagan Zhajylkandar [Jailkhani that inhabited the Peninsula] // road newspaper Aydin, April

Rasheed ad-din. (1999). Sbornik letopisei [Collection of Chronicles]. 2-book, Moskva.

Trepavlov V.V. (2002). Nogaiskaya Orda [Nogai Horde]. Moskva.

XIII-X gg. Nogai Ordasy. Soltystik Kazakstan zhane Batys. [XIII-X centuries Nogai Horde. North-Kazakhstan and Western].// https://qazbrand.info/all/510/ XIII-XV centuries-Nogai-ordasy-North Kazakhstan region/ Date 7.10.2018. 